\title{
Architecture_MPS
}

\section{Preserving Canadian Music Culture: The Case of the Silver Dollar Room and the Intangible Cultural Heritage Management of Urban Spaces of Culture}

Sara Gwendolyn Ross ${ }^{1}$

How to cite: Ross, S. G. 'Preserving Canadian Music Culture: The Case of the Silver Dollar Room and the Intangible Cultural Heritage Management of Urban Spaces of Culture.' Architecture_MPS, 2016, 10(1): 2. DOI:

https://doi.org/10.14324/111.444.amps.2016v10i2.001.

Published: 01 October 2016

\section{Peer Review:}

This article has been peer reviewed through the journal's standard double blind peer-review, where both the reviewers and authors are anonymised during review.

\section{Copyright:}

(C) 2016, The Author(s). This is an Open Access article distributed under the terms of the Creative Commons Attribution License (CC-BY) 4.0 https://creativecommons.org/licenses/by/4.0/, which permits unrestricted use, distribution and reproduction in any medium, provided the original author and source are credited • DOI: https://doi.org/10.14324/111.444.amps.2016v10i2.001.

\section{Open Access:}

Architecture_MPS is a peer-reviewed open access journal. 
Amps

\section{Title: Preserving Canadian Music Culture: The Case of the Silver Dollar Room and the Intangible Cultural Heritage Management of Urban Spaces of Culture}

\section{Author: Sara Gwendolyn Ross}

Architecture_media_politics_society. vol.10, no. 2.

October 2016

Affiliation: Osgoode Hall Law School, Toronto.

\section{Abstract}

On January 13, 2015, one of Toronto, Canada's, iconic live music venues, the Silver Dollar Room, officially received cultural heritage designation pursuant to the City of Toronto By-law 57-2015 under Part IV, Section 29 of the Ontario Heritage Act ("OHA"). What is significant about this designation, is that it was awarded, not on the basis of its physical or tangible heritage attributes but, instead, on the intangible cultural heritage value embodied within the space. Receiving cultural heritage designation is important for the future of the Silver Dollar Room as it has effectively led to the end of plans for its demolition and redevelopment that have been on the table since June 2013. By subjecting the redevelopment approval process to the greater scrutiny required due to cultural heritage designation, the interests of private developers have been better balanced with the artistic and cultural value of the Silver Dollar Room and the associated interests of the live music community culture linked to the space. This paper will examine these issues through the specific example of Toronto, but the implications of this study are applicable to the many rapidly developing cities around the world. 


\section{Title: Preserving Canadian Music Culture: The Case of the Silver Dollar Room and the Intangible Cultural Heritage Management of Urban Spaces of Culture}

\section{Author: Sara Gwendolyn Ross}

Architecture_media_politics_society. vol. 10, no.2.

October 2016

[T] he Silver Dollar was close by, right downstairs. Try to walk out the door past it. Try to come along Spadina Avenue, see that goddamn Silver Dollar sign, hundreds of light bulbs in your face, and not be drawn in there.

- The Silver Dollar Room immortalized in Elmore Leonard's 1989 thriller novel, Killshot. ${ }^{1}$

A great live show is a great thing. It makes a lot of people happy, it turns a lot of people on. Enriches their lives, enriches the lives of the bands.

- Dan Burke, the current booker and promoter for the Silver Dollar Room, discussing the role of live shows for audience members and attendees. ${ }^{2}$

I'm someone who doesn't really believe you build a career or a live music audience through putting out records or radio hits, you build them by playing live. You can never replicate that live experience of playing live in a small club at a grassroots level. It's an incredible thing.

- Brendan Canning, one of the founding members of the Canadian indie rock band Broken Social Scene discussing the role of live music shows for artists and performers. ${ }^{3}$

This is part of what is heritage in the city. It is not just the wood and the bricks and the mortar. Heritage is also cultural. It's where memories were shared, it's where moments happened. Music is a piece of heritage.

- Joe Cressy, City Councillor for Ward 20 (Trinity-Spadina), the ward within which the Silver Dollar is located. ${ }^{4}$ 


\section{Amps}

\section{Introduction}

On January 13, 2015, one of Toronto, Canada's, iconic live music venues, the Silver Dollar Room, officially received cultural heritage designation pursuant to the City of Toronto By-law 57-2015 under Part IV, Section 29 of the Ontario Heritage Act (OHA). ${ }^{5}$

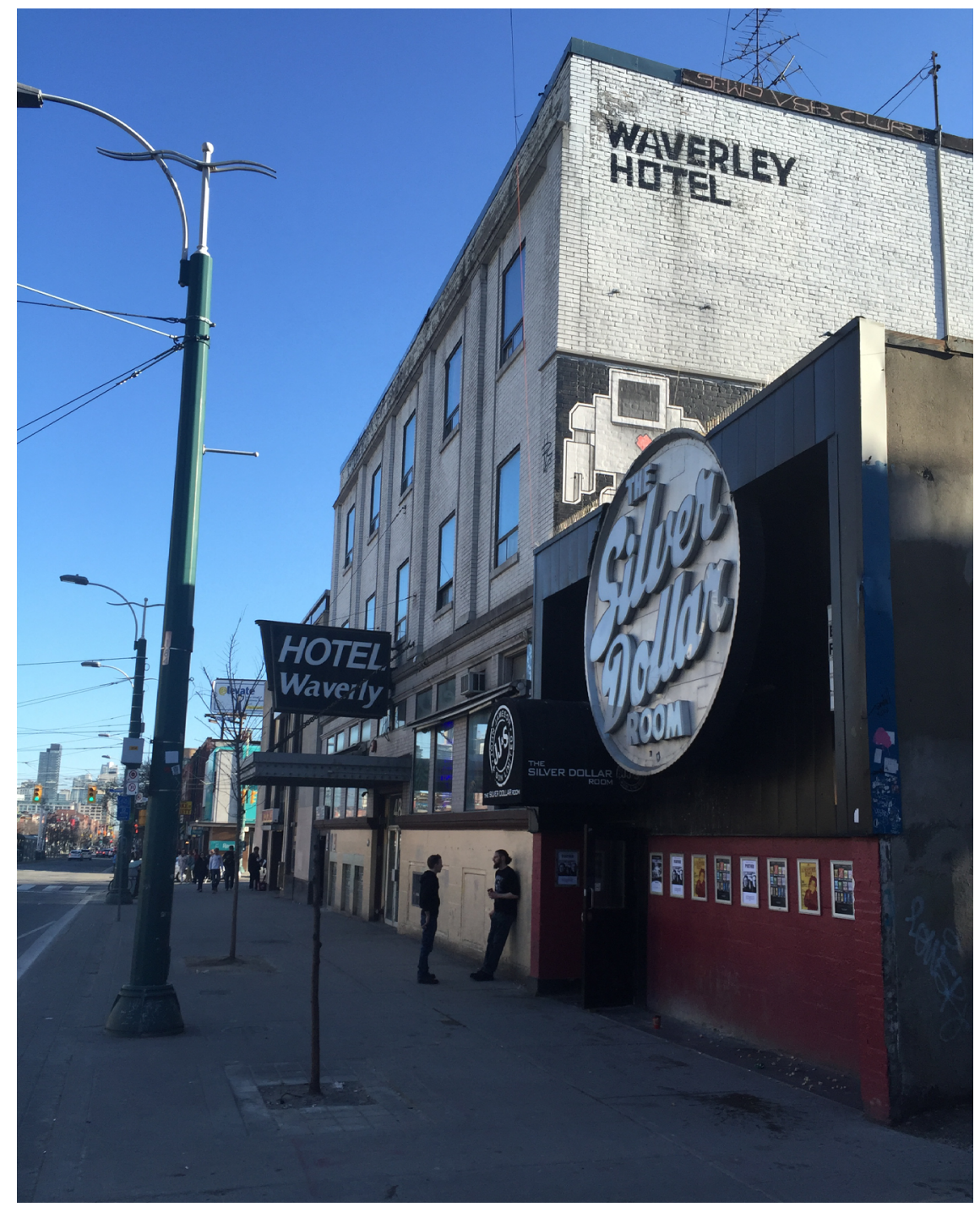

Figure 1. The Silver Dollar Room block, where the venue is located beside the Hotel Waverly. 


\section{Amps}

What is significant about this designation, is that it was awarded not on the basis of its physical or tangible heritage attributes but, instead, on the intangible cultural heritage value embodied within the space. ${ }^{6}$ Receiving cultural heritage designation is important for the future of the Silver Dollar Room as it has effectively led to the end of plans for its demolition and redevelopment that have been on the table since June 2013. ${ }^{7}$ By subjecting the redevelopment approval process to the greater scrutiny required due to cultural heritage designation, the interests of private developers have been better balanced with the artistic and cultural value of the Silver Dollar Room and the associated interests of the live music community culture linked to the space. ${ }^{8}$ This paper will examine these issues through the specific example of Toronto, but the implications of this study are applicable to the many rapidly developing cities around the world.

\section{The Use-Value of Cultural Spaces and the Rights in and to the Use of Cultural Spaces}

Toronto sociolegal scholar Mariana Valverde explains that municipal-level law and governance structures primarily function through the regulation of spaces and things via by-laws pertaining to the "use" and "activity" that occur within these spaces and of these things. ${ }^{9}$ She notes that this often results in only an indirect or secondary governance of the legal categories of persons, personhood, and group identity. ${ }^{10}$ Valverde asserts that what is needed in a further analysis and meaningful engagement with the context of municipal law and local governance, is a Foucauldian deconstruction of the binary of things versus persons, and nonhuman entities versus human entities. ${ }^{11}$ She draws on Foucault to displace the centrality of the person ${ }^{12}$ in order to explain that while "use" in the context of the municipal regulation of space and planning law constitutes a "legal technology" that draws together spaces, things, persons, and other entities, it does this in a manner that does not privilege persons. ${ }^{13}$ Valverde further reinforces this proposal by drawing on Bruno Latour's application of the actor-network theory, which also deconstructs the binary between the law of persons and the law of things (and spaces), and places all "actors" within a particular network on equal footing, whether the actor is a person or a thing. ${ }^{14}$

The crux of the argument here is for, on the one hand, a displacement of the centrality of the person, along with the focalization on a constitutional rightsbased approach, where these are not helpful in engaging with the notion of rights at the municipal and urban governance level due to the mechanics of boards, tribunals, and so on, that affect city planning, zoning, and city by-laws. But, on the other hand, neither should the entire focus be solely placed on the governance of space. Rather, a balanced approach free from a person/space differentiation is required, since engaging with the idea of rights in the city space, will more aptly enable communication with the legal context 


\section{Amps}

of municipal governance and planning/zoning law in order to necessarily also engage with the rights of persons and groups who use the city space.

Where certain groups of people use, value, create, produce, and "experientially consume" particular kinds of spaces within the city, they generates a use-value that is embodied within the space. ${ }^{15}$ Yet, Laam Hae notes a marked "disappearance of spaces for transgressive and alternative subcultures," such as live music venues and spaces for nighttime experiential production and consumption. ${ }^{16}$ Hae goes on to argue that this "implies a serious decline of people's rights; that is, people's rights to appropriate urban space and participate in producing it for the purpose of use-value, play, diverse social interactions, alternative community-building and the radical re-imagining of urban society." 17 These alternative spaces of use-value are also important in their opposition to the dominance of spaces of exchange-value in the city, and their encouragement of creation, production, and involvement in the city over pure consumption. ${ }^{18}$ It is ironic that "creativity"-focussed city regeneration projects, such as those at work in Toronto, necessarily focus on opportunities to commodify "creativity" and its potential market incentive in achieving an elevated global creative city status. But where spaces of intangible musical culture in Toronto are replaced with an iteration of a cleansed "creative" revitalization or redevelopment project, there is an irreversible replacement of use-value with exchange-value.

Reminiscent of Valverde's argument, Hae (with reference to the work of Don Mitchell) ${ }^{19}$ goes on to explain that the protection of spaces of use-value generated by

the mundane, basic activities in urban space - is not usually captured as constitutionally protected rights under liberal legalism (i.e. these mundane activities are not easily recognized as "speech" or "expression" that would entitle them with constitutional protections), which makes it hard for activists to legally challenge the gentrification and punitive policing that threaten to unduly regulate these activities. ${ }^{20}$

Thus, reimagining rights in the context of space as discussed by Valverde (or in Henri Lefebvre's work on the "right to the city" ${ }^{21}$ ) would involve safeguarding spaces of use-value "against colonization by market rationality"22 that is favored within many "culture"- and "creativity"-focussed regeneration projects, and even more notably in "gentrification projects with prominent urban scholars like Richard Florida and his 'Creative City' thesis encouraging the cultural turn in urban policies." 23 Further, a safeguarding of the usevalue in cultural spaces answers to the concerns expressed almost two decades ago in the UNESCO Action Plan on Cultural Policies for Development ("UNESCO Action Plan") in relation to the increasing interest of cities in the market-value of commodifiable elements of culture. ${ }^{24}$ As Lia Gudaitis and Martin Bunch summarize in applying the UNESCO Action Plan to the context of Toronto's Cultural Facilities Database, the UNESCO Action Plan 


\section{Amps}

warned cultural industrialists that cultural products were not like other trade goods, asserting that culture has additional social value that cannot be measured by market means. These debates highlight the importance of culture in catalyzing dialogue among individuals, and its potential for fostering shared cultural experiences, emphasizing the non-tangible benefits of culture. $^{25}$

\section{Use-Value and Toronto's Live Music and Cultural Spaces}

Protecting Toronto's live music venues, such as the Silver Dollar Room, from redevelopment projects and the gentrification of spaces is integral to the flourishing of Toronto's live music culture and nighttime arts scene in the city, and for the sustenance of this intangible element of Toronto's modern cultural heritage. Where legal frameworks govern the everyday experience of culture in the city through provincial and municipal zoning and planning decisions by bodies like the Ontario Municipal Board (OMB) and Toronto City Council, it is important to study how they manifest, or, as Valverde describes, "the microdetails of the governance process, rather than ... the bigpicture outcomes." 26

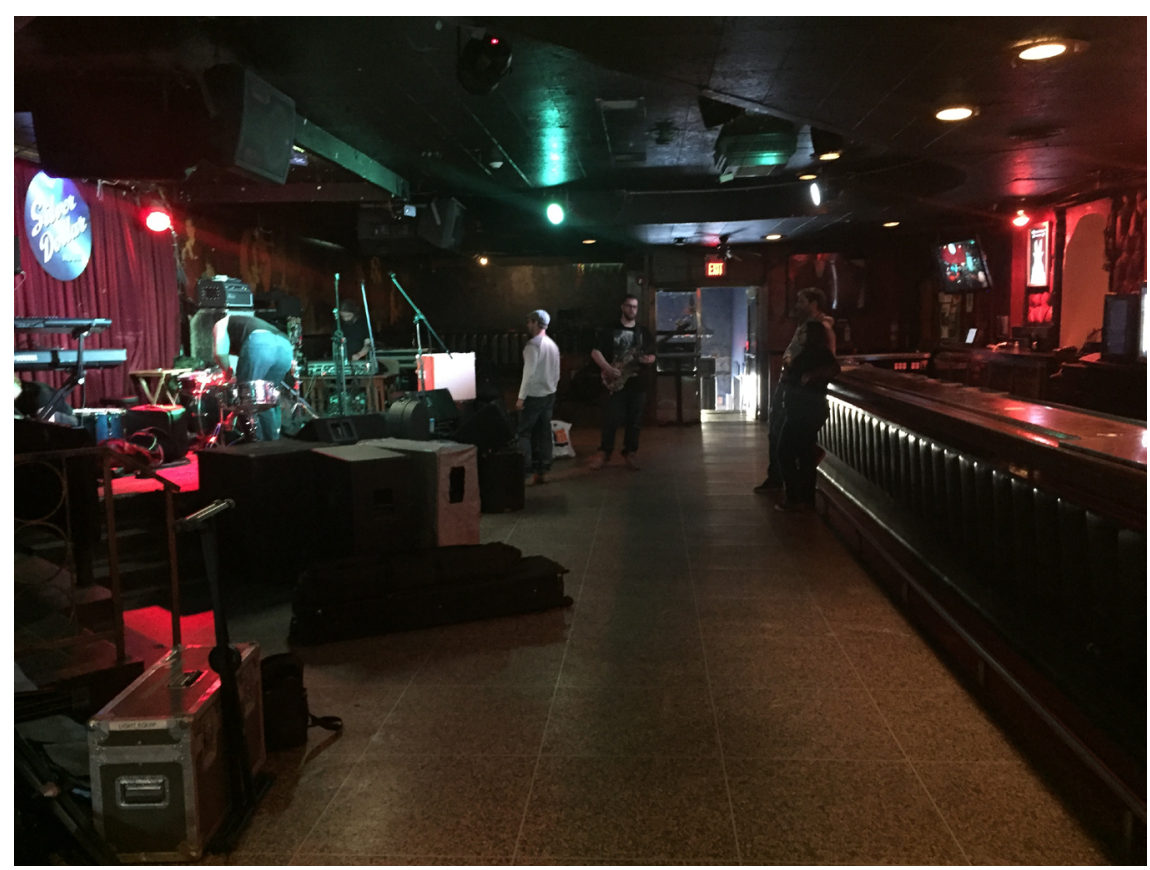

Figure 2. Interior of the Silver Dollar Room, viewed from the rear of the venue. The bar is on the right side and the stage is on the left. The center part is generally where the audience stands during live music performances. In this photo, a band is setting up their performance space for later that night. 


\section{Amps}

The governance processes at play in Toronto reveal a trend towards the private interests of developers, which tend to be aligned with post-industrial, creative-city oriented, and "culture" centric redevelopment projects that focus on generating and remaking spaces of culture. ${ }^{27}$ The application of Ontario's heritage legislation in a manner that enabled the cultural heritage designation of the Silver Dollar Room, based on the intangible cultural fabric woven within its walls, presents a strong example of how these legal frameworks may more effectively account for existing spaces of culture and cultural practices over the remaking of cultural spaces.

Furthermore, referring back to a more theoretical realm, improved regard for the protection of the intangible cultural heritage produced within urban cultural spaces at the municipal (or provincial) level speaks to Valverde's suggestion that more equitable city spaces may be arrived at through greater attention to, and perhaps a more effective commandeering of, municipal law's governance structure that primarily regulates through the "use" and "activity" that occurs within a space. ${ }^{28}$ Finally, the safeguarding of intangible cultural heritage within city spaces would create greater municipal accountability for what Hae describes as the "use-value" created by individuals within these spaces in the face of the exchange-value and market rationality of a developer's lucrative redevelopment or rejuvenation proposal. ${ }^{29}$

\section{Intangible Cultural Heritage in Canada and Toronto}

"Intangible cultural heritage" is defined at Article 2(1) of the 2003 UNESCO Convention on the Safeguarding of the Intangible Cultural Heritage ("2003 ICH Convention") as

the practices, representations, expressions, knowledge, skills - as well as the instruments, objects, artefacts and cultural spaces associated therewith - that communities, groups and, in some cases, individuals recognize as part of their cultural heritage. This intangible cultural heritage, transmitted from generation to generation, is constantly recreated by communities and groups in response to their environment, their interaction with nature and their history, and provides them with a sense of identity and continuity, thus promoting respect for cultural diversity and human creativity. ${ }^{30}$

While Canada is a signatory to the 1972 UNESCO Convention Concerning the Protection of the World Cultural and Natural Heritage has numerous World Heritage sites within its borders, ${ }^{31}$ it has yet to ratify the 2003 UNESCO Convention for the Safeguarding of Intangible Cultural Heritage and has not implemented any programs or policies explicitly designed to safeguard intangible cultural heritage. ${ }^{32}$

As such, most federal and provincial policies and legislation focus on tangible cultural heritage while intangible cultural heritage is largely ignored ${ }^{33}$ The focus on "heritage" as comprised of physical material things such as buildings, 


\section{Amps}

structures, and so on, is also reflected at the municipal and community level..$^{34}$ However, awareness of the concept of intangible cultural heritage is growing in prominence, especially for its availability as a way in which local communities or groups that identify with a living cultural practice and/or knowledge can become empowered in identity-construction and preservation strategies. ${ }^{35}$

A few reasons are cited for the yet-unratified state of the $2003 \mathrm{ICH}$ Convention in Canada. Concerns include the view that the definition of intangible cultural heritage that appears in the $2003 \mathrm{ICH}$ Convention is too vague, and that the obligations that the 2003 ICH Convention would impose on the State are too onerous to fulfill - such as the creation and maintenance of inventories of Canada's intangible cultural heritage - due to the multicultural nature of Canada's population. ${ }^{36}$ In addition, since cultural policy is predominantly a provincial matter, another reason suggested is that the federal government is waiting to see if provincial interest exists for this somewhat new category of heritage protection and, if there is interest, is awaiting input from the provinces. ${ }^{37}$

Quebec is the first province to establish its own provincial legislation addressing the preservation of elements of intangible cultural heritage, which was adopted on October 19, 2011 and came into effect on October 19, 2012. ${ }^{38}$ In accordance with Article 12 of the 2003 ICH Convention, Quebec's Cultural Heritage Act mandates the compilation of a complete inventory of intangible cultural heritage within the province. ${ }^{39}$ Steps have also been taken in Newfoundland and Labrador towards concretely recognizing, recording, promoting, and safeguarding their intangible cultural heritage through, for example, their provincial strategic cultural plans. ${ }^{40}$

Additionally, various reports and initiatives of provinces, such as Ontario, have grasped onto the notion that intangible elements of culture are important to develop, promote, and protect. ${ }^{41}$ For example, in 2010, subsequent to "a series of consultation sessions to determine the significant issues facing heritage preservation and the heritage community in Toronto," Heritage Toronto and the Toronto Historical Association compiled a set of recommendations that noted a "lack of emphasis on, and protections afforded at the provincial level to intangible heritage resources." 42 The report also noted the necessity for both Toronto and local heritage organizations "to update their perspective and broaden their scope in order to reflect a more diverse definition of 'heritage', one that includes intangible heritage resources, cultural landscapes and natural heritage resources as well as built heritage."43

It is within this context that the heritage preservation legislation of provinces, such as Ontario, currently contain language that is increasingly interpreted so as to include intangible elements of lived cultural practices. Examining the reasons for which the Silver Dollar received cultural heritage protection and By-law 57-2015, provides an example of this kind of interpretation. The "associative" and "contextual" heritage criteria set out in Ontario Regulation 9/06 were interpreted to include the elements of intangible musical culture and heritage within the space of the Silver Dollar as worthy of cultural heritage protection. ${ }^{44}$ This gestures towards the premise of intangible cultural heritage protection. 


\section{Amps}

\section{The Silver Dollar Room}

\section{Description of the Space}

The Silver Dollar Room is located on the west side of Spadina Avenue, just north of College Street, in Toronto, Ontario, attached to the side of the

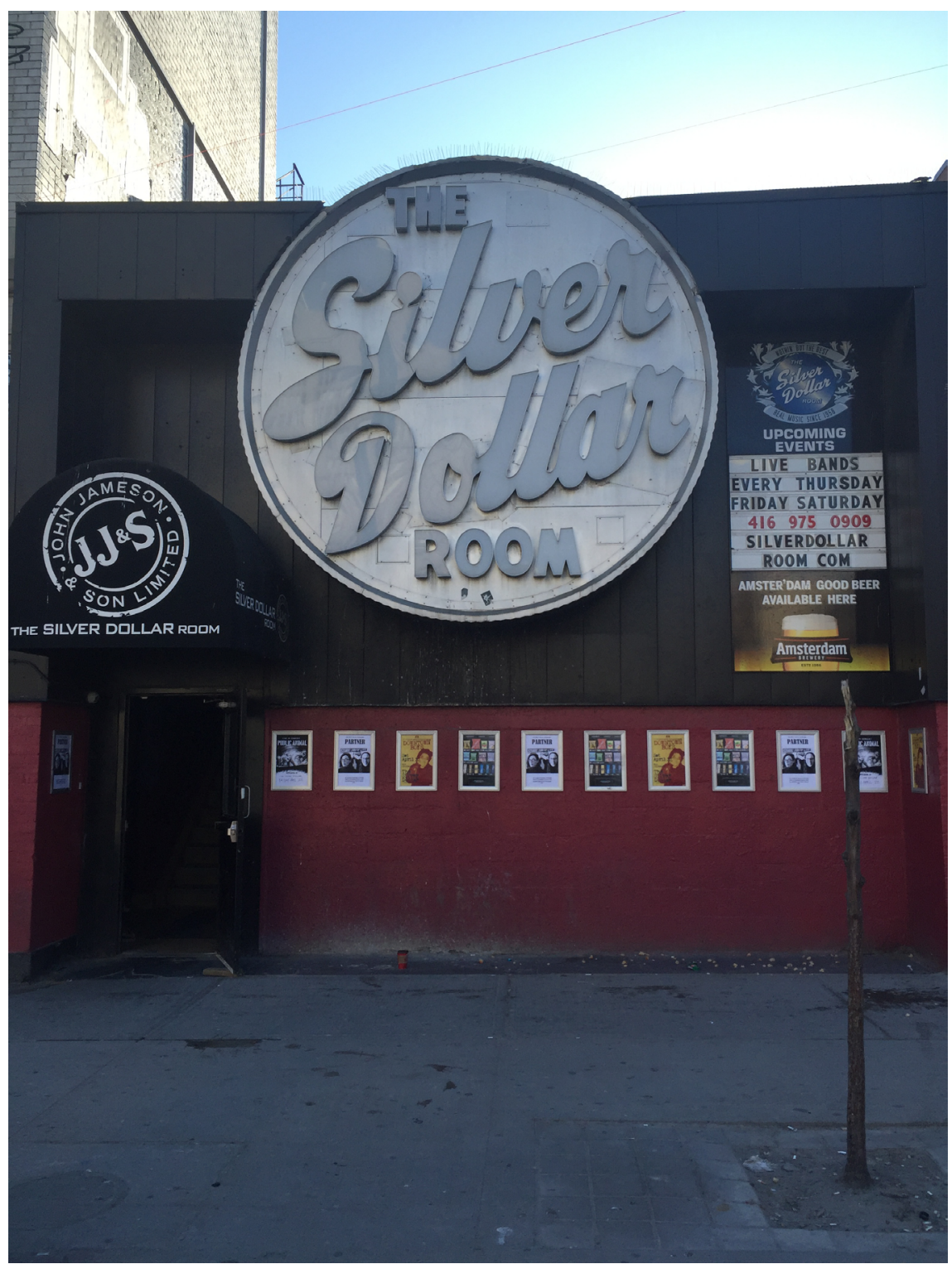

Figure 3. Exterior of the Silver Dollar Room, with its iconic sign. 


\section{Amps}

Waverly Hotel. ${ }^{45}$ The building is recognizable by its brick façade painted red and black and its imposing large circular and brightly lit sign bearing the venue's name, Silver Dollar Room, written in slanted cursive letters.

The stairs inside of the Silver Dollar Room's entrance head up to the main part of the venue. There is also a set of stairs that lead down to Comfort Zone, an electronic music venue and dance club in the Waverly Hotel's basement that does not serve alcohol. Sometimes the parties at Comfort Zone will use the space of the Silver Dollar Room as an additional room to host another set of DJs for the night - in this case the stairs that connect to Comfort Zone inside the Silver Dollar Room entrance will be opened up. Climbing the stairs that lead into the Silver Dollar, one is greeted with another Silver Dollar Room sign overhead, and the walls alongside the stairs are lined with autographed photographs of acts that played the Silver Dollar Room in its days as an iconic blues venue.

Past this, there is a door with a glass window that leads into the main venue. The interior is laid out in a narrow horizontal fashion, with a raised stage area on the right-hand side backed with either a red curtain or white fabric to facilitate projections, depending on the show, and divided from the room with the various speakers and amps that comprise its sound system. A raised seating area is found along the rear end of the right wall and is divided from another row of tables and chairs on the main level by a wrought iron railing. The bar runs along the left-hand side of the room and, in addition to some more black and white photographs, the walls are covered with colourful murals on a black background that depict images of the bygone era of blues that played such a formative role in Silver Dollar's rich musical past. Behind the bar, amidst the bar paraphernalia and in front of the red leather chesterfield walls, a red and white electric guitar bearing the Molson Canadian logo is mounted vertically.

The speckled terrazzo tile floors recall the formulaic floor tiling of eightiesera Canadian elementary schools. ${ }^{46}$ Much like the lighting system, the floors are no-frills - plain but practical. A door on the far end of the bar leads to a semi-secluded room that is more brightly lit but retains a dingy warm yellow hue complementing the row of dull green padded banquettes found along one wall, which call to mind a worn hybridized greasy-spoon diner and tired hotel dive bar. The other wall is lined with regular wooden tables and chairs. Wood paneling climbs halfway up all of the white walls, which are peppered with black and white photographs. A couple of pool tables sit near the end of the room facing Spadina Avenue.

When the music begins, most patrons gravitate to the center of the room in front of the stage. The audiences move to the music, but usually not to the extent that would lead one to mistake the Silver Dollar Room for a dancing-oriented venue. The long narrow space of the Silver Dollar could not be described as optimized for dancing, not that attendees appear concerned or affected by this, as the main path from one side of the room to the other necessarily crosses through the crowd clustered in front of the stage. 


\section{Amps}

\section{History, Music, and Culture}

Originally built as the cocktail lounge of the Waverly Hotel in 1957-58, the Silver Dollar Room soon held performances of live blues music as well as jazz, rock, and bluegrass in Toronto. Despite its modest beginnings, brief turn as a strip club in the 60s, and its share of police raids in the 70s and $80 \mathrm{~s},{ }^{47}$ the Silver Dollar Room quickly grew to be a mecca for live blues music in Toronto, quickly gained an international reputation, and continues to be important within Toronto's music scene today - both for the development as well as the growth of indie music culture in Toronto. ${ }^{48}$

As noted by By-law 57-2015's Statement of Cultural Heritage Value, in addition to acts like Bob Dylan, the walls of the Silver Dollar have seen the likes of "John T. Davis, Tommy Okie and Jim Heineman, Grammy award winner Bobby 'Blue' Bland, Juno-award winners Fathead and the Downchild Blues Band, the Deadly Snakes and Death from Above 1979, Blue Rodeo bassist Bazil Donovan, and the Foggy Hogtown Boys." 49 The Silver Dollar has made film cameos (Adventures in Babysitting and Police Academy) and hosted live album recordings by performers such as jazz and blues saxophonist David "Fathead" Newman in 2004 and jazz and rhythm-and-blues pianist and vocalist Curley Bridges in 2009. ${ }^{50}$

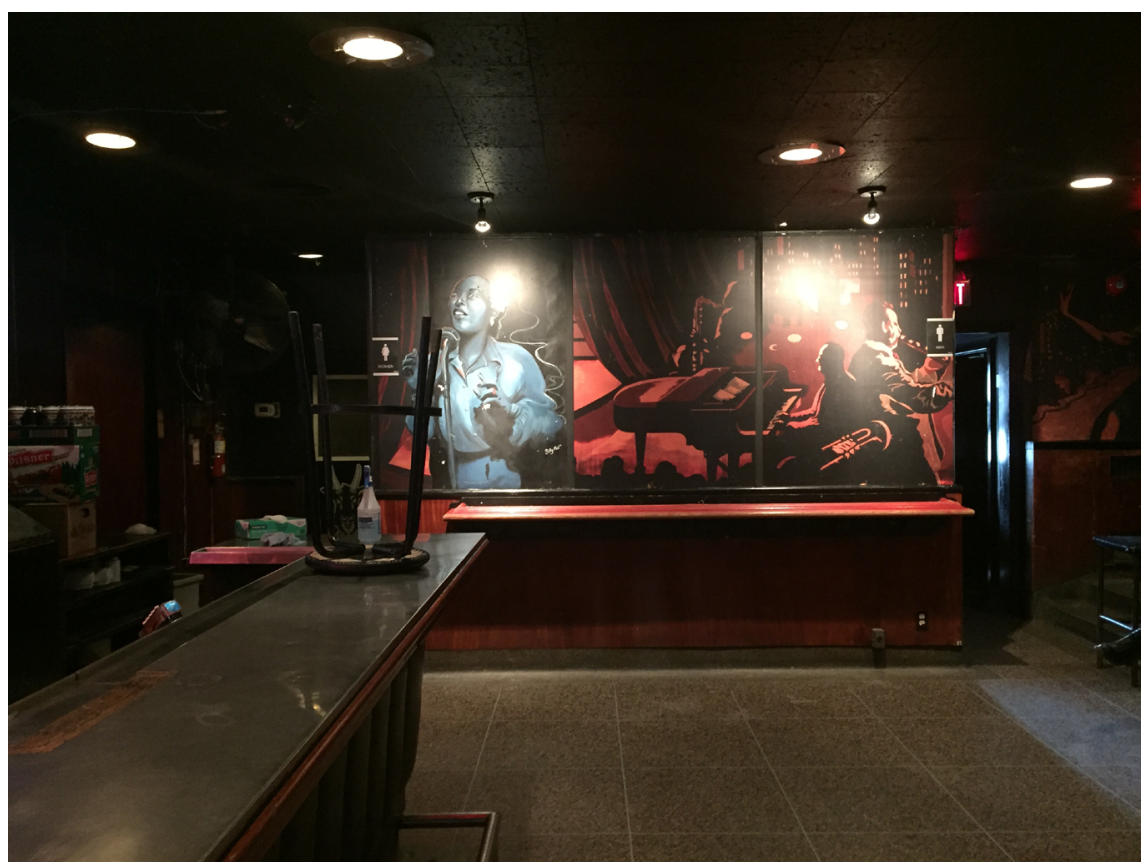

Figure 4. Example of mural work on the interior walls of the Silver Dollar Room.

This mural is located on the rear wall of the space and features jazz musicians playing beside a female vocalist. 


\section{Amps}

But perhaps more significant than the international acts the Silver Dollar Room has drawn and its international reputation, By-law 57-015 also recognizes the cultural heritage value of its role "as an incubator for musical talent. From the 1960s onwards it has often functioned as a workshop for new and sometimes struggling musicians, both local and transient, to sit-in with moreestablished musicians, to develop their music and to build up a following." ${ }^{51}$

\section{The Legal Process: Zoning, Space, and Culture}

There are two particular forms of zoning laws that comprise the framework within which the Silver Dollar Room's struggle to stay alive was and is framed. The first, the threat or potential disabler, was in the form of a proposed amendment to Zoning By-law 438-86 made by the Wynn Group (who own the spaces of the Waverly, the Silver Dollar Room, and Comfort Zone), which sought rezoning to allow for "a 22 -storey mixed-use development containing 202 residential units and approximately 1,600 square metres of commercial space." 52 This would effectively have enabled the Wynn Group's proposal to replace the Waverly, the Silver Dollar Room, and Comfort Zone with a high-rise mixed-use complex with twenty-stories dedicated to a private student residence to house approximately 200 students, a Wynn Fitness Club on the second-floor, three levels of underground parking, and a new replacement tavern intended to "re-create" the Silver Dollar Room, which would be located on the ground floor with the famous sign placed on the inside and no longer visible to passersby. ${ }^{53}$

The proposal first began to circulate in the Summer of 2013 and soon received unfavorable treatment by the Toronto Planning Department in their Preliminary Report. ${ }^{54}$ Other reports followed,${ }^{55}$ and eventually the proposal was rejected by Toronto and East York Community Council in early 2014 and subsequently appealed by the Wynn Group to the Ontario Municipal Board. ${ }^{56}$ The proposal was rejected for a number of reasons but, in sum, because "[t]he proposed density, building height, and lack of transition [did] not reinforce or respect the physical character of the existing neighbourhood," such that the intent of the City of Toronto's Official Plan could not be met. ${ }^{57}$ Nonetheless, "City Planning Staff ... indicated a willingness to work with the applicant to achieve a development which [might] be supportable for this site and is in keeping with the policies contained within the Official Plan." 58

The second kind of zoning law within which the Silver Dollar Room's struggle was framed, and which enabled its safeguarding, was the context of cultural heritage management. In terms of the mechanics of how the OHA is applied, the Toronto Preservation Board, assisted by the Heritage Preservation Services, advises Toronto's City Council in matters related to the OHA. Part IV of the OHA specifically provides municipalities with the ability to pass by-laws designating selected properties to be of "cultural heritage value or interest." ${ }^{59}$ In 2005 the OHA was amended to offer stronger protection, provide more specific designation criteria, and allow municipalities to more effectively stop the demolition of heritage-designated properties. ${ }^{60}$ The 


\section{Amps}

OHA at Section 29(1)(a) refers municipal council to Ontario Regulation 9/06 for the "Criteria for Determining Cultural Heritage Value or Interest." 61

One or more of these criteria must be met for heritage-designation status. The first criterion speaks to the design or physical value of a property and considers elements such as the architecture primarily, method of construction, artistic merit, or technical or scientific achievement. The second criterion considers whether there is either historical or associative value to the property in relation to a particular culture or community. In order to determine this, research is carried out to ascertain whether there is direct association between the property and a significant person or event, or if the property either contributes or potentially contributes to the understanding of a community or culture, or if the property exemplifies the work or ideas of an architect, builder, designer or theorist of note to a particular community. The third criterion asks subjectively whether the property has contextual value - whether the property in question serves a role in defining, maintaining or supporting the character of an area, if it is vitally linked through physical, functional, visual, or historical means to the surrounding area, or if it is a landmark. ${ }^{62}$

What is unique about the cultural heritage designation and protection afforded to Silver Dollar is that it is not based on physical or tangible heritage attributes (the first criteria of Regulation 9/06) but, instead, it is based on the intangible cultural heritage value embodied within the space and for "its contribution to Toronto's musical culture." ${ }^{63}$ Or, as it is framed under Regulation 9/06 and in By-law 57-2015, the Silver Dollar meets the Section 29 criteria in terms of "associative and contextual value." Its associative value was primarily determined based on its historical association with "the development and growth of music in Toronto, particularly the genres of jazz, blues, rock and bluegrass, from the 1950s through to the present day," its role as "an incubator for musical talent," its "international reputation that allowed local bands to be booked internationally," and the important musicians associated with its space. ${ }^{64}$ Its contextual value was determined based on its "value as a landmark in Toronto by virtue of it being a well-known, long-standing destination for live music with an international reputation," as well as for its "important contribution to Toronto's musical scene," especially within the context of other similar venues in the area, such as Grossman's Tavern, the El Mocambo, and the Horseshoe Tavern. As such, the Silver Dollar was also deemed important for its role in preserving "this particular aspect of the cultural character of Spadina Avenue." ${ }^{65}$

On September 12, 2011, the Toronto and East York Community carried the motion brought by former City Councillor for Ward 20 (Trinity-Spadina) Adam Vaughan to request "the Acting Director, Policy and Research, City Planning Division, to consider listing and designating as Heritage Properties 484 Spadina Avenue (The Waverly Hotel) and 486 Spadina Avenue (The Silver Dollar Room). ${ }^{66}$ This action originated in the letter to this effect written by Adam Vaughan to the Toronto and East York Community Council. ${ }^{67}$ 


\section{Amps}

Based on its assessment of the March 20, 2014 "Report from the Director, Urban Design, City Planning Division, respecting Intention to Designate under Part IV, Section 29 of the Ontario Heritage Act - 484 Spadina Avenue," as well as a series of communications between March 24 and March 26, 2014, with individuals (listed in the document), on March 31, 2014 the Toronto Preservation Board recommended to the Toronto and East York Community Council that "City Council state its intention to designate the property at 484 Spadina Avenue under Part IV, Section 29 of the Ontario Heritage Act in accordance with the Statement of Significance: 484 Spadina Avenue (Reasons for Designation)," but that it should "refer the Waverly Hotel portion of the property at 484 Spadina Avenue to the Director, Urban Design, City Planning Division, for further review for designation under Part IV, Section 29 of the Ontario Heritage Act." 68

The Toronto and East York Community Council went on to follow these recommendations and carve out the Waverly Hotel portion of the 484 Spadina property for further review by the Director of Urban Design in Toronto's City Planning Division. After completing further review, the Director of Urban Design in Toronto's City Planning Division ultimately recommended on June 23, 2014, that the Waverly Hotel not receive heritage designation under Section 29 (Part IV) of the OHA and that it should not be added to the City of Toronto Inventory of Heritage, namely because the Waverly did not meet Ontario Regulation $9 / 06{ }^{69}$ The Toronto Preservation Board in turn followed this recommendation, ${ }^{70}$ despite objections from the Harbord Village Residents' Association, ${ }^{71}$ and City Councillor for Ward 20 (at the time) Ceta Ramkhalawansingh. ${ }^{72}$

Subsequent to this, the Toronto and East York Community Council followed this recommendation..$^{73}$ However, in terms of the Silver Dollar Room portion of 484 Spadina, Toronto City Council indeed gave its Notice of Intention to designate, to which there was no notice of objection, and City Council enacted and passed the designation on December 11, 2014. ${ }^{74}$ By-law 57-2015 subsequently came into force on January 13, 2015. ${ }^{75}$

\section{The Results of Heritage Protection for the Silver Dollar Room: A Happy Ending?}

On May 8, 2015, those who generate and enjoy the use-value and intangible live music culture of the Silver Dollar Room, the Silver Dollar Room itself, cultural heritage preservationists, current Ward 20 (Trinity-Spadina) City Councillor Joe Cressy, and Harbord Village Residents' Association Chair Tim Grant, all breathed a collective sigh of relief as the lengthy appeal process at the OMB came to a close after hard negotiations ended in a settlement agreement between the City of Toronto, on the one side, and the private developer and owner of the space (the Wynn Group), on the other. ${ }^{76}$

In addition to a decrease in the height of the proposed development down to fifteen stories from twenty-two stories, a decrease in the shadow impact of the new construction on a nearby school and its playground, the heritage 


\section{Amps}

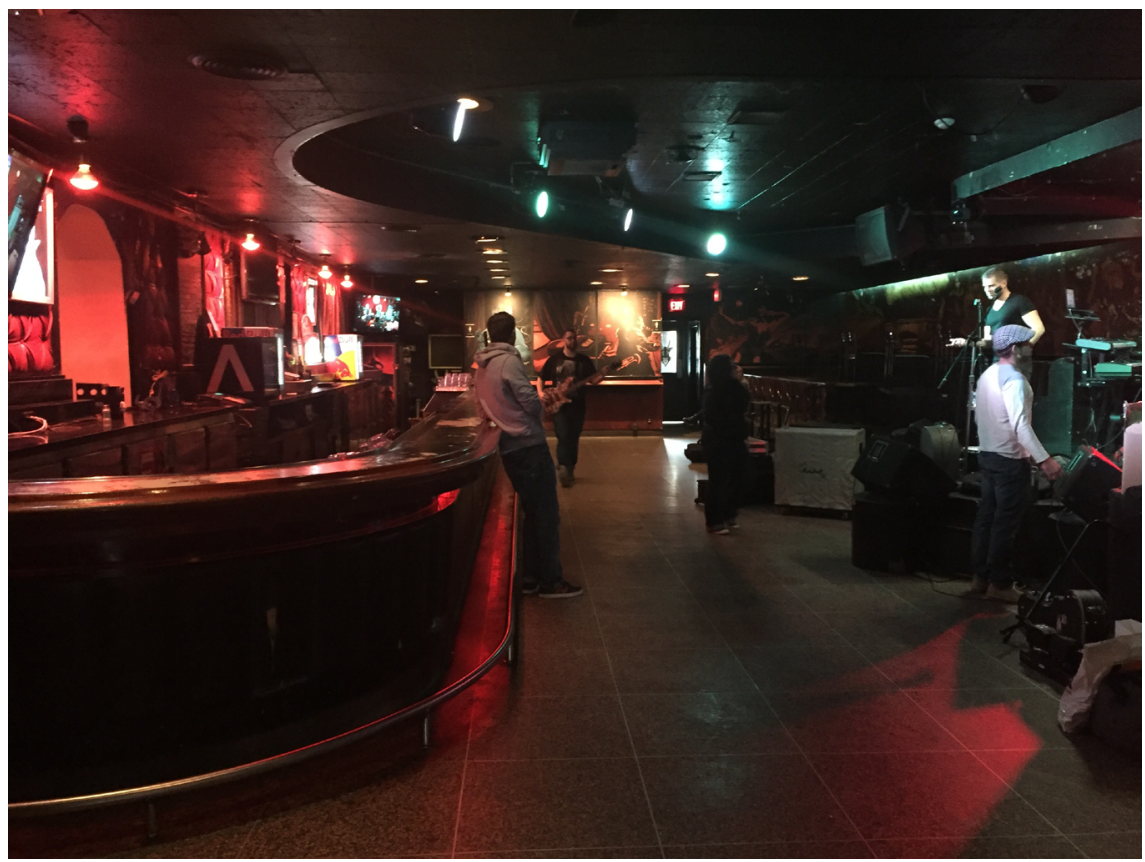

Figure 5. Interior of the Silver Dollar Room viewed from the entrance side of the space. The bar area is to the left, and the stage is to the right. In this photo a band is setting up its performance space for later that night.

status designation of the Silver Dollar Room led to encouraging results for its future and the preservation of its intangible cultural heritage and high generated use-value. ${ }^{77}$ The new development will involve the heritage restoration and maintenance of the current space of the Silver Dollar Room as well as its iconic sign, and will also be constructed in a manner that emphasizes the built form of the Silver Dollar. ${ }^{78}$ In particular, conservation measures

shall include retaining: the location, scale, form and massing of the existing resource, the location of the original entrance, the exterior "Silver Dollar Room" sign and its location on the east elevation, the open volume of the interior performance space including the bar, the stage with raised areas and the terrazzo floor. Conservation and commemoration of other heritage elements of the premise will, as part of the site plan approval conditions, include reinstatement of the original mural and photographs of entertainers, installation of a plaque to commemorate the heritage resources, re-use of the name "Silver Dollar" in connection with the entertainment component of the commercial land use. ${ }^{79}$

But, while the heritage protection afforded by By-Law 57-2015 made it more difficult for the Silver Dollar to be demolished until a final favorable decision 


\section{Amps}

regarding the development proposal was made, heritage protection did not function as a bar against demolition. Rather, heritage designation simply made it more difficult for this to happen, by requiring the owner of a Section 29 designated property (the Wynn Group in the case of Silver Dollar Room) to apply to the council of the municipality within which the property is located in order to obtain written consent for demolition. ${ }^{80}$ Effectively, as expressed by current City Councillor for Ward 20 (Trinity-Spadina) Joe Cressy, heritage designation simply "means we put another piece of furniture at the door" - it gives the city another chance to say no to demolition. ${ }^{81}$ It is also important to remember that another obstacle the Silver Dollar faced in its struggle to stay intact was that the Waverly, to which the Silver Dollar is attached, did not receive heritage designation, ${ }^{82}$ and, neither has the infamous after-hours electronic music venue and dance club Comfort Zone downstairs, which has been ignored in the discussions and negotiations related to the property. ${ }^{83}$

As discussed previously, the cultural heritage designation of the Silver Dollar Room accorded based on "use" or "function" within the space appears to be the sticking point in criticisms that arose in relation to By-law 57-2015, ${ }^{84}$ which is a reason that the Silver Dollar is an interesting case study in Toronto, where heritage designations are predominantly given based on architectural merit. In addition, the protection of the Silver Dollar is unique as Toronto's City Council is not known for its interest in protecting bars, whether or not the bar hosts live music. ${ }^{85}$ City Councillors, such as former councillor Adam Vaughan, who played an important role in acquiring protection for the Silver Dollar, are not known for supporting the preservation of bars either. Rather, the opposite is true..$^{86}$

\section{The Route to a "Cultural" City: Heritage Preservation, Redevelopment/Revitalization, and Other Threatened Live Music Venues}

In the 2010 report derived from the series of consultations conducted by Heritage Toronto and the Toronto Historical Association, which looked into heritage preservation issues in Toronto, a recurring frustration of those consulted identified the provincial planning processes as problematic to preservation goals. ${ }^{87}$ The OMB was identified as especially problematic in its tendency to favor the interests of developers over concerns with the safeguarding of cultural heritage. ${ }^{88}$

As the document notes, while there have been a few exceptions where the $\mathrm{OMB}$ has elected cultural heritage preservation to the detriment of a development proposal, ${ }^{89}$ the situation remains unbalanced in favor of developers. The Silver Dollar Room's intangible cultural heritage protection represents one of these exceptions, but one must only consider the nearly concurrent closure of the iconic Guvernment music venue in favor of a mixed-use development project and the city's waterfront redevelopment plans to see that more consultation must occur leading up to these decisions. ${ }^{90}$ 


\section{Amps}

Where profitability is desired of intangible live musical culture and its associated spaces in the city, and may provide incentives for protection, it appears that market incentives can be positive if nourished with the right tools, such as sufficiency in venue supply. ${ }^{91}$ The end of 2014 saw the launch of Measuring Live Music Canada, a study designed to measure the economic impact of live music in Ontario. ${ }^{92}$ As stated by the President of Music Canada, Graham Henderson, "We know that live music is an essential piece of our music story in Ontario and yet, no one has truly tried to capture the extent of its impact on our economy, workforce and communities." $" 93$

This study comes on the heels of the 2013 report commissioned by Music Canada to explore new strategies to support and grow Canada's music industry ${ }^{94}$ In addition, the live music assets of cities are identified for their potentially significant economic return in terms of "music tourism," 95 and the report highlights the abilities of a rich music scene to attract the sought-after "creative class", and the attached economic benefits that their presence brings to a city. ${ }^{96}$

The formulation of these aspirations and initiatives for the future of live musical culture in Ontario and Toronto fit into an overarching trend in urban cultural policy and post-industrial city redevelopment strategies that focuses on and valuates "culture" as the panacea for attaining sought-after global creative city status. ${ }^{97}$ But even though these musical culture initiatives that capitalize on existing forms of musical heritage comprise part of creative city planning initiatives, other municipal policy and planning documents that express the same creative city aspirations can ultimately deploy conflicting strategies. ${ }^{98}$

Waterfront renewal in Toronto, for example - and the rezoning that has occurred to alter the land from its industrial past to one that will accommodate mixed-use commercial and residential areas ${ }^{99}-$ is one of Toronto's most prominent redevelopment/revitalization mega-projects. ${ }^{100}$ Administered by Waterfront Toronto, ${ }^{101}$ incorporated into Toronto's Official Plan, ${ }^{102}$ governed by the Central Waterfront Secondary Plan, ${ }^{103}$ and further elaborated in the East Bayfront Precinct Plan, ${ }^{104}$ the East Bayfront Precinct is the most central area part of the waterfront rejuvenation plan and one of the first precincts undergoing the process.

This is the area where the previously mentioned Guvernment Entertainment Complex used to be located before its recent demolition. While the space occupied by Guvernment was privately owned and is not part of the specific portions of land owned by Waterfront Toronto that are undergoing citymandated rejuvenation, the nature of the new "Daniels Waterfront - City of the Arts" development proposed for the space is clearly designed as a complement to the city's newly rejuvenated and cleansed "creative" waterfront vision. ${ }^{105}$ While the notion of heritage was considered in designing Toronto's waterfront renewal, the relevant documents do not effectively address all manners of cultural heritage, and glaze over the value of many of the existing cultural elements and spaces that make up, or used to make up, the waterfront 


\section{Amps}

area - such as Guvernment. ${ }^{106}$ The lack of consideration of the existing intangible cultural heritage within the waterfront space exemplifies the lack of regulatory balancing discussed previously. ${ }^{107}$ Unlike the case of the Silver Dollar, Guvernment's creative and live music assets were not considered in the development of an area for creative purposes.

Finally, beyond the contradictions within municipal legal and governance frameworks that seek out certain forms of generated "culture" while simultaneously destroying other forms of existing and often organically derived culture and cultural spaces, more serious consideration must be paid to the destruction of spaces of high use-value and intangible cultural heritage within the city. Without greater attention to this matter, cities like Toronto run the risk of losing the spaces where urban citizens weave their lives and cultural fabric, and derive meaning within the city. Or - as Sharon Zukin would assert - these cities run the risk of losing their soul. ${ }^{108}$

\section{Notes}

1 Elmore Leonard, Killshot, revised ed. (Harper Collins, 2009), 7.

2 Interview with Dan Burke (March 11, 2013) on Canadian Reflections, "The Last Music Man”, CBC Television, accessed September 9, 2016, https://web.archive. org/web/20131115092855/http://www.cbc.ca/player/Shows/ID/2341910245/.

3 Interview with Brendan Canning, see note 2.

4 Codi Wilson, "Silver Dollar Will Live on as Live Music Venue", CP24, accessed September 9, 2016, http://www.cp24.com/news/silver-dollar-will-liveon-as-live-music-venue-1.2365609.

5 City of Toronto, By-law No 57-2015, To designate the property at 484 Spadina Avenue (Silver Dollar Room) as being of cultural heritage value or interest (December 11, 2014) [By-law 57-2015]; Ontario Heritage Act, RSO 1990, c O.18 [OHA].

6 The term "space" is used, not in the architectural sense, but interchangeably with "place" and, more specifically, "space" refers particularly to the area within or outside of the walls of a place, building, or venue where intangible cultural heritage and subcultural community wealth is generated. "Space" is also used in the context of critical, legal geography scholarship, see generally, for e.g., Irus Braverman et al., eds., The Expanding Spaces of Law: A Timely Legal Geography (Stanford: Stanford University Press, 2014). See also generally Henri Lefebvre, The Production of Space, translated by Donald Nicholson-Smith (Malden, MA: Blackwell Publishing, 1991), and especially Henri Lefebvre, The Production of Space, 53.

7 See e.g., "484 Spadina Avenue - Zoning Amendment Application. Staff Report Action Required," August 19, 2013 [Staff Report, August 19, 2013]; 1095909 Ontario Ltd. (c.o.b. Wynn Group of Companies) v Toronto (City), [2014] OMBD No 498, OMB Case No PL131176 [Wynn v Toronto, OMB Appeal]. See e.g., Patty Winsa, "Toronto Rejects Proposal to Tear Down Hotel Waverly and Silver Dollar Room for Student Housing," thestar.com (January 15, 2014), accessed 
August 5, 2016, online <www.thestar.com>; Richard Longley, "Re: Hotel Waverly (484 Spadina Ave) and The Silver Dollar Room (486 Spadina Ave)," Architectural Conservancy Ontario, online email, March 26, 2014, 3, accessed August 5, 2016; Gregg Lintern, Director, Community Planning, Toronto and East York District, "Staff Report Action Required - 484 Spadina Ave - Zoning Amendment Application - Request for Direction Report," November 22, 2013, 3. For the settlement between, on the one side, the City of Toronto and Silver Dollar Room advocates and, on the other side, the private developer, the Wynn Group, see Wilson, "Silver Dollar Will Live On"; Justin Skinner, "OMB Settlement a Good Deal for Spadina and College Neighbourhood," InsideToronto.com, accessed August 5, 2016, http://www.insidetoronto.com/ news-story/5614271-omb-settlement-a-good-deal-for-spadina-and-collegeneighbourhood/; Letter from Joe Cressy (Ward 20 City Counsellor), Ausma Malik (Toronto District School Board Ward 10 Trustee) and Tim Grant (Chair of the Harbord Village Resident's Association) to neighbourhood residents re: "Resolution on 484 Spadina Avenue (the Waverley and Silver Dollar Room) (May 8. 2015).

8 OHA, s 34(1).

9 Mariana Valverde, "Taking Land Use Seriously: Toward an Ontology of Municipal Law" (2005) Law, Text, Culture 9:1 (2005): 34, 37, accessed August 5, 2016. [Valverde, "Land Use"].

10 Ibid., 36-7.

11 Ibid., 36, 38.

12 Ibid., 55. See also Michel Foucault, The Order of Things: An Archaeology of the Human Sciences, ed by R. D. Laing (New York: Pantheon Books, 1970).

13 Valverde, "Land Use," 38.

14 Ibid., 36-8. See also Bruno Latour, Science in Action (Cambridge, Mass: Harvard University, 1987); Bruno Latour, We Have Never Been Modern (Cambridge, Mass: Harvard University Press, 1993).

15 Laam Hae, The Gentrification of Nightlife and the Right to the City: Regulating Spaces of Social Dancing in New York (New York: Routledge, 2012), 13.

16 Ibid., 6.

17 Ibid.

18 Paul Chatterton and Robert Hollands, Urban Nightscapes: Youth Cultures, Pleasure Spaces and Corporate Power (London, UK: Routledge, 2003), 238.

19 Don Mitchell, "Property Rights, the First Amendment, and Judicial AntiUrbanism: The Strange Case of Virginia v Hicks" Urban Geography 26(7) (2005), 565.

20 Hae, Gentrification of Nightlife, 6.

21 An in-depth discussion of the right to the city is beyond the scope of this paper, but see especially Henri Lefebvre, "The Right to the City," in Writings on Cities, eds. E. LeBas and E. Kofman (Cambridge, MA: Blackwell, 1996), 63. See also Hae, Gentrification of Nightlife, 34-9.

22 Hae, Gentrification of Nightlife, 6.

23 Hae, Gentrification of Nightlife, 4. 


\section{Amps}

24 See "The Power of Culture - The Intergovernmental Conference on Cultural Policies for Development" (Stockholm: March-April 1998) (adopted April 2, 1998); Lia Gudaitis and Martin J Bunch, "[Multi]culture and the City: The Representation of Culture in Toronto's Cultural Facilities Database," Canadian Journal of Urban Research 17(1): 1, 5.

25 Ibid.

26 Mariana Valverde, Everyday Law on the Street: City Governance in an Age of Diversity (Chicago: University of Chicago Press, 2012), 3. [Valverde, Everyday].

27 City of Toronto, Culture Division, Culture Plan for the Creative City (Toronto: Culture Division, 2003); AuthentiCity, "Creative City Planning Framework: A Supporting Document to the Agenda for Prosperity: Prospectus for a Great City" (Toronto: City of Toronto, 2008) [AuthentiCity, "Creative City"]; Central Waterfront Secondary Plan (2003) (approved in full by the OMB in 2007); "Daniels Waterfront Planning Application", \#14 249503 STE 28 SA for 142 Lake Shore Blvd East, Toronto Development Projects, accessed May 4, 2015, http//:app.toronto.ca; \#14 249503 STE 28 SA for 142 Lake Shore Blvd East, Toronto Development Projects, accessed May 4, 2015, http://app.toronto.ca.

28 Valverde, "Land Use," 35, 53-4.

29 Hae, Gentrification of Nightlife, 6. See also Chatterton and Hollands, Urban Nightscapes, 238 (Hae's notion of "use-value" draws on their work).

30 Convention on the Safeguarding of the Intangible Cultural Heritage, October 17, 2003, 2368 UNTS 3 (entered into force April 20, 2006) [2003 ICH Convention]. Per Article 2(3), "safeguarding" indicates "measures aimed at ensuring the viability of the intangible cultural heritage, including the identification, documentation, research, preservation, protection, promotion, enhancement, transmission, particularly through formal and non-formal education, as well as the revitalization of the various aspects of such heritage."

31 November 16, 1972, 1037 UNTS 151 (entered into force December 17, 1975). See also Richard MacKinnon, "The UNESCO Convention for the Safeguarding of Intangible Cultural Heritage and its Implications for Sustaining Culture in Nova Scotia," in Michelle L Stefano, Peter Davis and Gerard Corsane, Safeguarding Intangible Cultural Heritage (Woodbridge: Boydell Press, 2012) 153.

32 Antoine Gauthier, "Intangible Cultural Heritage in Canada: Political Context, Safeguarding Initiatives, and International Cooperation," Quebec Council for Intangible Cultural Heritage/Conseil Québécois du Patrimoine Vivant (CQPV), accessed August 6, 2016, http://patrimoinevivant.qc.ca/wp-content/ uploads/2013/04/Intangible-Heritage-in-Canada-ICHCAP-publishing.pdf, 4; 2003 ICH Convention, 30.

33 MacKinnon, "The Unesco Convention," 153.

34 Ibid.

35 Ibid., 153-4.

36 Gauthier, "Intangible Cultural Heritage in Canada," 2.

37 MacKinnon, "The Unesco Convention," 159.

38 Cultural Heritage Act, CQLR, c P-9.002, s 1: "Cultural heritage consists of deceased persons of historical importance, historic events and sites, heritage 


\section{Amps}

documents, immovables, objects and sites, heritage cultural landscapes, and intangible heritage" (emphasis added). Ibid, s 2 defines intangible heritage as "the skills, knowledge, expressions, practices and representations handed down from generation to generation and constantly recreated, in conjunction with any cultural objects or spaces associated with them, that a community or group recognizes as part of its cultural heritage, the knowledge, protection, transmission or enhancement of which is in the public interest."

39 Ibid., ss 5-8; MacKinnon, "The Unesco Convention," 159; Gauthier, "Intangible Cultural Heritage in Canada," 3, 5-6.

40 Newfoundland and Labrador's Strategic Priority Seven of its provincial strategic cultural plan (Government of Newfoundland and Labrador, "Creative Newfoundland and Labrador: The Blueprint for Investment and Development in Culture" (2006), 34. Newfoundland and Labrador favor the term "living heritage". See also Gauthier, "Intangible Cultural Heritage in Canada," 4.

41 Music Canada, "Measuring Live Music in Canada", accessed August 5, 2016, http://musiccanada.com/campaigns/measuring-live-music-in-ontario-stand-upand-be-counted [Measuring Live Music].

42 Heritage Toronto and the Toronto Historical Association, "Heritage Voices: A Report Presented by Heritage Toronto and the Toronto Historical Association" (February 2011), accessed August 5, 2016, http://heritagetoronto.org/wp-content/ uploads/2014/07/Heritage-Voices-Report-20111.pdf, 4, 7 [“Heritage Voices”].

43 Ibid.

44 O Reg 9/06.

45 By-law 57-2015, 2.

46 Ibid., 3.

47 Tom Beedham, "Historic Venue Spotlight: The Silver Dollar Room," Noisey [blog], (July 9, 2014), accessed August 5, 2016, http://noisey.vice.com/en_ca/read/ historic-venue-spotlight-the-silver-dollar-room.

48 By-law 57-2015, 2.

49 Ibid. See also Brad Wheeler, "Why the Silver Dollar is Worth Saving," The Globe and Mail (January 23, 2015), accessed August 5, 2016, http:// www.theglobeandmail.com/news/toronto/why-the-silver-dollar-is-worth-saving/ article22606865/; Leslie Ferenc, "Silver Dollar Room Now a Heritage Site", thestar.com (January 13, 2015), accessed August 5, 2016, https://www.thestar. com/news/gta/2015/01/13/silver_dollar_room_now_a_heritage_site.html.

50 Beedham, Historic Venue Spotlight; By-law 57-2015, 2. Film credits include Adventures in Babysitting and Police Academy (Beedham, Historic Venue Spotlight); Toronto, Urban Design, City Planning Division, "Intention to Designate under Part IV, Section 29 of the Ontario Heritage Act - 484 Spadina Avenue" (March 20, 2014), 11.

51 By-law 57-2015, 2.

52 See e.g., Wynn v Toronto, OMB Appeal.

53 See e.g., Winsa, "Toronto Rejects Proposal"; Longley, Re: Hotel Waverly, 3; "Request for Direction Report", November 22, 2013, 3. 


\section{Amps}

54 "Staff Report," August 19, 2013.

55 See e.g., "Request for Direction Report," November 22, 2013.

56 Winsa, "Toronto Rejects Proposal"; See also Wynn v Toronto, OMB Appeal; Letter from Mark Flowers at Davies Howes Parners LLP to Toronto and East York Community Council (January 14, 2014).

57 "Request for Direction Report," November 22, 2013, 11. See also City of Toronto, Ontario Municipal Board, Official Plan (Toronto: City of Toronto, July 2006 [Official Plan].

58 "Request for Direction Report," November 22, 2013, 11.

59 OHA; By-law 57-2015.

60 Cf RSO 1990, c O.18 as it appeared before April 28, 2005. See also Message from the Honourable Madeleine Meilleur, Minister of Culture, "Strengthening Ontario's Heritage: An Introductory Guide to Identifying, Protecting, and Promoting the Heritage of our Communities" (Toronto: Queen's Printer for Ontario, 2005), 3.

61 O Reg 9/06, s 1(2).

62 Ibid.

63 By-law 57-2015.

64 Ibid., 2.

65 Ibid.

66 Toronto and East York Community Council, “Agenda Item” (September 11, 2011), accessed August 5, 2016, http://app.toronto.ca/tmmis/viewAgendaItemHistory. do?item=2011.TE9.93.

67 Letter from Adam Vaughan to the Toronto and East York Community Council (September 8, 2011).

68 Toronto Preservation Board, "Recommendation re: Intention to Designate under Part IV, Section 29 of the Ontario Heritage Act - 484 Spadina Avenue" (March 31, 2014). See By-law 57-2015, 1-3 for the "Statement of Significance: Reasons for Designation."

69 Meaning that the Waverly does not meet the criteria stipulated for s 29 designation under O Reg 9/06; Toronto, Director Harold Madi, Urban Planning, City Planning Division "Heritage Evaluation - 484 Spadina Avenue - Waverly Hotel, Staff Action Report Required" (June 23, 2014) [Heritage Evaluation, Action Required, June 23, 2014].

70 Toronto Preservation Board, Agenda Item PB 3315, "Heritage Evaluation - 484 Spadina Avenue - Waverley Hotel” (July 17, 2014).

71 Letter from Sue Dexter to the Toronto Preservation Board (July 16, 2014). The Harbord Village Residents' Association represents those who live between College and Bloor and Spadina and Bathurst.

72 Letter from Ceta Ramkhalawansingh to the Toronto Preservation Board (July 16, 2014).

73 See also "Is Hotel Waverly's Lurid Past Keeping it from Heritage Designation?" CBC News (July 19, 2014), accessed August 5, 2016, http://www.cbc.ca/news/ canada/toronto/is-hotel-waverly-s-lurid-past-keeping-it-from-heritagedesignation-1.2711343. 
74 By-law 57-2015, 1.

75 See e.g., Ferenc, "Silver Dollar Room."

76 Wilson, "Silver Dollar Will Live on"; Skinner, "OMB Settlement"; Cressy, Malik \& Grant, "Resolution on 484 Spadina Avenue."

77 Cressy, Malik \& Grant, "Resolution on 484 Spadina Avenue."

78 Ibid.

79 City Council Decision re: 484 Spadina Avenue: Zoning By-law and Site Plan Appeals (Adopted May 5, 2015), accessed May 4, 2016, http://app.toronto.ca.

80 OHA, s 34(1).

81 Ferenc, "Silver Dollar Room."

82 Heritage Evaluation, Action Required, June 23, 2014.

83 Beedham, "Historic Venue Spotlight." See also Jackson Hayes, "33 Arrested in Club Raid, Drugs Seized," accessed August 5, 2016 2016, thestar.com (March 17, 2008), https://www.thestar.com/news/gta/2008/03/17/33_arrested_in_club_raid_ drugs_seized.html; Shawn Jeffords, "Vaughan in Legal Fight with Bar", Toronto Sun (October 10, 2012), accessed August 5, 2016, http://www.torontosun. com/2012/10/10/vaughan-in-legal-fight-with-bar; Kirk Makin, "Nightclub Sues City for Harassment," The Globe and Mail (March 9, 2009, updated April 10, 2009), accessed August 5, 2016, http://www.theglobeandmail.com/news/national/ toronto-nightclub-sues-city-for-harassment/article1149853/.

84 See e.g., Comment by W. M. Johnston on a BlogTO article (Chris Bateman, "The Silver Dollar Could Get Heritage Protection" BlogTO [blog] (March 24, 2014), accessed August 5, 2016, http://www.blogto.com/city/2014/03/ the_silver_dollar_could_get_heritage_protection/.

85 Sebastien Darchen and Diane-Gabriel Tremblay, "The Local Governance of Culture-led Regeneration Projects: A Comparison between Montreal and Toronto," Urban Research \& Practice 6(2) (2013): 140, 150.

See also Valverde, Everyday, 90; Bateman, "Silver Dollar Could Get Heritage Protection," 87. See also the Daniels Waterfront Planning Application. For a further discussion of this and the Guvernment Entertainment Complex, see infra note 90 .

86 Valverde, Everyday, 90; Interview of Adam Vaughan by Raju Mudhar (May 28, 2007) thestar.com, accessed August 5, 2016, http://www.thestar.com/ entertainment/2007/05/28/interview_trascript_councillor_adam_vaughan.html. See also Joshua Ostroff, “Gord Perks and Toronto’s War on Hipsters,” Huffington Post [blog] (July 16, 2013), accessed 4 May 2016, http://www.huffingtonpost.ca/ joshua-ostroff/parkdale-gentrification-gord-perks_b_3602328.html.

87 "Heritage Voices", 5.

88 Ibid.

89 Ibid., 5 , fn 2.

90 The recent closure of Guvernment ended its approximately twenty-year prolific contribution to Toronto and to Canada's music culture. It was iconic for the many musical acts that performed within its walls over the years; for the development of both Canada's own electronic music and scene as well as for the international reputation that the venue commanded within the international 


\section{Amps}

electronic scene; for the important role it played in developing robust musical subcultures that remain today, such as Toronto's, Ontario's, and Canada's "drum 'n' bass" musical subculture; and for its role as a space for nascent entrepreneurs in the music industry - such as promoters, musicians, and DJs. Nonetheless, rather than any recognition by the city council that preservation for past and ongoing cultural importance and as a draw for international music acts and fans, its demolition for replacement with a mixed-use condo and arts development "Daniels Waterfront - City of the Arts" by one of Toronto's dominant development corporations (see the Daniels Waterfront Planning Application, note 27) has been heralded by important city actors, such as current mayor, John Tory (following up on the initiative begun by prior mayors), within the context of Toronto's waterfront redevelopment plans and focus on creative city-modeled regeneration strategies. See also David Shum, "Daniels Corporation Unveils Waterfront Mixed-Use Condo Project", Global News (March 26, 2015), accessed August 5, 2016, http://globalnews.ca/news/1904704/ daniels-corporation-to-unveil-waterfront-mixed-use-condo-project/; Susan Pigg, "\$700-Million Arts-Focused Complex Planned for Queens Quay Site", thestar. com (26 March 2015), accessed August 5, 2016, https://www.thestar.com/ business/2015/03/26/700-million-arts-focused-complex-planned-for-queensquay-site.html; Darryl Coote, "Mayor Tory Breaks Ground on \$700 million Waterfront Development" (March 27, 2015), accessed August 5, 2016, https:// nowtoronto.com/news/mayor-tory-breaks-ground-on-700-million-waterfrontdevelopm/; Denise Benson, "Then \& Now: The Guvernment Complex" (March 7, 2015), Then \& Now: Toronto's Nightlife History [blog], accessed August 5, 2016, http://thenandnowtoronto.com/2015/03/now-guvernment-complex/.

91 Robert J Foster, Karen Kain and Jim Prentice, Creative Capital Gains: An Action Plan for Toronto (2011), accessed August 5, 2016, http://www. torontoartsfoundation.org/tac/media/taf/Research/Foundation $\% 20$ Publications/Creative-Capital-Gains-Report.pdf, 25.

92 See "Measuring Live Music." See also Foster, Kain and Prentice, Creative Capital Gain.

93 See "Measuring Live Music." See also Foster, Kain and Prentice, Creative Capital Gain.

94 Music Canada, "The Next Big Bang: A New Direction for Music in Canada” (2013), accessed August 5, 2016, http://musiccanada.com/wp-content/uploads/2014/06/ TheNextBigBang.pdf, 1.

95 Ibid, 2-3.

96 Ibid, 5-6, 42. See also Richard Florida, The Rise of the Creative Class: And How It's Transforming Work, Leisure, Community and Everyday Life (New York: Basic Books, 2002); and see Strategies for a Creative City Project, "Toronto Case Study" (London-Toronto: 2006), 22, 36 [Strategies for a Creative City Project, "Toronto Case Study"]. See further, Richard Florida, Cities and the Creative Class (New York: Routledge, 2005). The "creative class" is a rather ambiguous and malleable concept but can be loosely summarized as workers in art, design, and technology industries (see Carl Grodach and Daniel Silver, 
"Introduction: Urbanizing Cultural Policy," in Carl Grodach and Daniel Silver, eds, The Politics of Urban Cultural Policy: Global Perspectives (London, UK: Routledge, 2013), 1, 4. See also, Ute Lehrer and Jennifer Laidley, "Old Mega-Projects Newly Packaged? Waterfront Redevelopment in Toronto," International Journal of Urban and Regional Research 32(4) (2008): 786, 794; Ute Lehrer, Roger Keil and Stefan Kipfer, "Reurbanization in Toronto: Condominium Boom and Social Housing Revitalization," Planning Review 46(180), 81, 82.

97 See e.g., Grodach and Silver, "Introduction: Urbanizing Cultural Policy," 2, 4; Ute Lehrer and Andrea Winkler, "Public or Private? The Pope Squat and Housing Struggles in Toronto" Social Justice 33(3) (2006): 142, 144; Lehrer and Laidley, “Old Mega-Projects Newly Packaged?” 794, 796.

98 See e.g., City of Toronto, Culture Plan for the Creative City; AuthentiCity, "Creative City"; Strategies for a Creative City Project, "Toronto Case Study", 22, 36.

99 Lehrer and Laidley, "Old Mega-Projects Newly Packaged?".

100 See the City of Toronto's Waterfront Renewal page on their website, accessed August 5, 2016, http://www1.toronto.ca/wps/portal/contentonly?vgnextoid=8c4 8e26b1af51410VgnVCM10000071d60f89RCRD. See also, Waterfront Toronto, accessed August 5, 2016, http://www.waterfrontoronto.ca.

101 Toronto Waterfront Revitalization Corporation Act, SO 2002, c 28; Waterfront Toronto; Lehrer and Laidley, “Old Mega-Projects Newly Packaged?”, 791.

102 Official Plan.

103 Central Waterfront Secondary Plan.

104 Toronto Waterfront Revitalization Corporation, (2005) City of Toronto, accessed August 5, 2016, https://www1.toronto.ca/city_of_toronto/waterfront_ secretariat/files/pdf/eb_precinct_plan_pt1.pdf.

105 Official Plan, s 2.2.1; City of Toronto, Culture Plan for the Creative City; AuthentiCity, "Creative City"; Foster, Kain and Prentice, Creative Capital Gains. See footnote 93 for a discussion of Guvernment.

106 See e.g., Toronto Cultural Planning, "Canada's Urban Waterfront: Waterfront Culture and Heritage Infrastructure Plan" (2001).

107 Robert Winthrop, "Defining a Right to Culture, and Some Alternatives," Cultural Dynamics 14(2) (2002): 161, 174.

108 Sharon Zukin, Naked City: The Death and Life of Authentic Urban Places (Oxford: Oxford University Press, 2010), xi, 9, 246.

\section{Bibliography}

1095909 Ontario Ltd. (c.o.b. Wynn Group of Companies) v Toronto (City), [2014] OMBD No 498, OMB Case No PL131176.

"484 Spadina Avenue - Zoning Amendment Application. Staff Report Action Required." August 19, 2013.

AuthentiCity. "Creative City Planning Framework: A Supporting Document to the Agenda for Prosperity: Prospectus for a Great City." Toronto: City of Toronto, 2008. 


\section{Amps}

Beedham, Tom. "Historic Venue Spotlight: The Silver Dollar Room." Noisey, July 9, 2014. Accessed August 6, 2014. http://noisey.vice.com/en_ca/read/ historic-venue-spotlight-the-silver-dollar-room.

Benson, Denise. Then \& Now: Toronto's Nightlife History. Accessed August 6, 2014. http://thenandnowtoronto.com/2015/03/now-guvernment-complex/.

Braverman, Irus et al., eds. The Expanding Spaces of Law: A Timely Legal Geography. Stanford: Stanford University Press, 2014.

Central Waterfront Secondary Plan (2003) (approved in full by the OMB in 2007).

Chatterton, Paul and Robert Hollands. Urban Nightscapes: Youth Cultures, Pleasure Spaces and Corporate Power. London, UK: Routledge, 2003.

"City Council Decision re: 484 Spadina Avenue: Zoning By-law and Site Plan Appeals.” Adopted May 5, 2015. http://app.toronto.ca.

City of Toronto. By-law No 57-2015, To designate the property at 484 Spadina Avenue (Silver Dollar Room) as being of cultural heritage value or interest (December 11, 2014).

City of Toronto, Culture Division. Culture Plan for the Creative City. Toronto: Culture Division, 2003.

City of Toronto, Ontario Municipal Board. Official Plan. Toronto: City of Toronto, July 2006.

City of Toronto. "Toronto Waterfront Revitalization Corporation." Accessed May 4, 2016. https://www1.toronto.ca/city_of_toronto/waterfront_secretariat/files/pdf/ eb_precinct_plan_pt1.pdf.

City of Toronto. "Waterfront Renewal." Accessed August 6, 2016. http://www1. toronto.ca/wps/portal/contentonly?vgnextoid=8c48e26b1af51410VgnVCM10000 071d60f89RCRD.

Coote, Darryl. "Mayor Tory Breaks Ground on \$700 million Waterfront Development." NowToronto.com, (March 27, 2015). Accessed August 6, 2016. https://nowtoronto.com/news/mayor-tory-breaks-ground-on-700-millionwaterfront-developm/.

Convention Concerning the Protection of the World Cultural and Natural Heritage. November 16, 1972. 1037 UNTS 151 (entered into force December 17, 1975).

Convention on the Safeguarding of the Intangible Cultural Heritage. October 17, 2003. 2368 UNTS 3 (entered into force April 20, 2006).

Cressy, Joe (Ward 20 City Counsellor), Ausma Malik (Toronto District School Board Ward 10 Trustee), and Tim Grant (Chair of the Harbord Village Resident's Association). "Letter to neighbourhood residents re: 'Resolution on 484 Spadina Avenue (the Waverley and Silver Dollar Room)'." May 8, 2015.

Cultural Heritage Act, CQLR, c P-9.002.

Daniels Waterfront development, planning application: “\#14 249503 STE 28 SA for 142 Lake Shore Blvd East.” Toronto Development Projects. Accessed May 4, 2015. http://app.toronto.ca.

Darchen, Sebastien and Diane-Gabriel Tremblay. "The Local Governance of Cultureled Regeneration Projects: A Comparison between Montreal and Toronto." Urban Research and Practice 6 (2013): 140-57.

Dexter, Sue. "Letter to the Toronto Preservation Board.” July 16, 2014. 


\section{Amps}

Ferenc, Leslie. "Silver Dollar Room Now a Heritage Site." thestar.com, January 13, 2015. Accessed August 6, 2016. https://www.thestar.com/news/gta/2015/01/13/ silver_dollar_room_now_a_heritage_site.html.

Florida, Richard. Cities and the Creative Class. New York: Routledge, 2005.

Florida, Richard. The Rise of the Creative Class: And How It's Transforming Work, Leisure, Community and Everyday Life. New York: Basic Books, 2002.

Flowers, Mark. "Letter to Toronto and East York Community Council." January 14, 2014.

Foster, Robert J, Karen Kain and Jim Prentice. "Creative Capital Gains: An Action Plan for Toronto." Accessed August 6, 2016. http://www.torontoartsfoundation. org/tac/media/taf/Research/Foundation\%20Publications/Creative-Capital-GainsReport.pdf.

Foucault, Michel. The Order of Things: An Archaeology of the Human Sciences. Edited by R. D. Laing. New York: Pantheon Books, 1970.

Gauthier, Antoine. "Intangible Cultural Heritage in Canada: Political Context, Safeguarding Initiatives, and International Cooperation." Quebec Council for Intangible Cultural Heritage/Conseil Québécois du Patrimoine Vivant (CQPV). Accessed August 6, 2016. http://patrimoinevivant.qc.ca/wp-content/ uploads/2013/04/Intangible-Heritage-in-Canada-ICHCAP-publishing.pdf>.

Government of Newfoundland and Labrador. "Creative Newfoundland and Labrador: The Blueprint for Investment and Development in Culture." 2006.

Grodach, Carl and Daniel Silver. "Introduction: Urbanizing Cultural Policy." In The Politics of Urban Cultural Policy: Global Perspectives, edited by Carl Grodach and Daniel Silver, 1-19. London, UK: Routledge, 2013.

Gudaitis, Lia and Martin J Bunch. "[Multi]culture and the City: The Representation of Culture in Toronto's Cultural Facilities Database." Canadian Journal of Urban Research 17 (2008): 1-27.

Hae, Laam. The Gentrification of Nightlife and the Right to the City: Regulating Spaces of Social Dancing in New York. New York: Routledge, 2012.

Hayes, Jackson. "33 Arrested in Club Raid, Drugs Seized." thestar.com, March 17, 2008. Accessed August 6, 2016. https://www.thestar.com/news/gta/2008/03/17/33_ arrested_in_club_raid_drugs_seized.html.

Heritage Toronto and the Toronto Historical Association. "Heritage Voices: A Report Presented by Heritage Toronto and the Toronto Historical Association." February 2011. Accessed August 6, 2016. http://heritagetoronto.org.

"Is Hotel Waverly's Lurid Past Keeping it from Heritage Designation." $C B C$ News, July 19, 2014. Accessed August 6, 2016. http://www.cbc.ca/news/ canada/toronto/is-hotel-waverly-s-lurid-past-keeping-it-from-heritagedesignation-1.2711343.

Jeffords, Shawn. "Vaughan in Legal Fight with Bar." Toronto Sun, October 10, 2012. Accessed August 6, 2016. http://www.torontosun.com/2012/10/10/ vaughan-in-legal-fight-with-bar.

Johnston, W.M.Commenton BlogTOarticlebyChris Bateman, "TheSilverDollarCould Get Heritage Protection.” BlogTO, March 24, 2014. Accessed August 6, 2016. http:// www.blogto.com/city/2014/03/the_silver_dollar_could_get_heritage_protection/. 


\section{Amps}

Latour, Bruno. Science in Action. Cambridge, Mass: Harvard University, 1987.

Latour, Bruno. We Have Never Been Modern. Cambridge, Mass: Harvard University Press, 1993.

Lefebvre, Henri. The Production of Space. Translated by Donald Nicholson-Smith. Malden, MA: Blackwell Publishing, 1991.

Lefebvre, Henri. "The Right to the City." In Writings on Cities, edited by E LeBas and E. Kofman, 63-85. Cambridge, MA: Blackwell, 1996.

Lehrer, Ute and Jennifer Laidley. "Old Mega-Projects Newly Packaged? Waterfront Redevelopment in Toronto." International Journal of Urban and Regional Research 32 (2008): 786-803.

Lehrer, Ute and Andrea Winkler. "Public or Private? The Pope Squat and Housing Struggles in Toronto." Social Justice 33 (2006): 142-57.

Lehrer, Ute, Roger Keil, and Stefan Kipfer, "Reurbanization in Toronto: Condominium Boom and Social Housing Revitalization." disP: Planning Rev 46 (2010): 81-90.

Leonard, Elmore. Killshot. revised ed. New York: Harper Collins, 2009.

Lintern, Gregg. Director, Community Planning, Toronto and East York District. "Staff Report Action Required - 484 Spadina Ave - Zoning Amendment Application - Request for Direction Report.” November 22, 2013.

Longley, Richard. Architectural Conservancy Ontario, "Re: Hotel Waverly (484 Spadina Ave) and The Silver Dollar Room (486 Spadina Ave)." March 26, 2014.

MacKinnon, Richard. "The UNESCO Convention for the Safeguarding of Intangible Cultural Heritage and its Implications for Sustaining Culture in Nova Scotia." In Safeguarding Intangible Cultural Heritage, edited by Michelle L. Stefano, Peter Davis, and Gerard Corsane, 153-64. Woodbridge: Boydell Press, 2012.

Madi, Harold (Toronto, Director Urban Planning, City Planning Division). "Heritage Evaluation - 484 Spadina Avenue - Waverly Hotel, Staff Action Report Required." June 23, 2014.

Makin, Kirk. "Nightclub Sues City for Harassment." The Globe and Mail, March 9, 2009. Accessed August 6, 2016. http://www.theglobeandmail.com/news/national/ toronto-nightclub-sues-city-for-harassment/article1149853/.

Meilleur, Madeleine (Minister of Culture). "Strengthening Ontario's Heritage: An Introductory Guide to Identifying, Protecting, and Promoting the Heritage of our Communities.” Toronto: Queen's Printer for Ontario, 2005.

Mitchell, Don. "Property Rights, the First Amendment, and Judicial Anti-Urbanism: The Strange Case of Virginia v Hicks." Urban Geography 26 (2005): 565-86.

Music Canada. "Measuring Live Music in Canada." Accessed 6 August 2016. http:// musiccanada.com/campaigns/measuring-live-music-in-ontario-stand-up-and-becounted.

Music Canada. "The Next Big Bang: A New Direction for Music in Canada." Accessed May 4, 2016. http://musiccanada.com/wp-content/uploads/2014/06/ TheNextBigBang.pdf. Accessed 6 August 2016.

Ontario Heritage Act. RSO 1990, c O.18.

Ontario Regulation 9/06, O Reg 9/06. 


\section{Amps}

Ostroff, Joshua. "Gord Perks and Toronto's War on Hipsters." Huffington Post, July 16, 2013. Accessed August 6, 2016. http://www.huffingtonpost.ca/joshuaostroff/parkdale-gentrification-gord-perks_b_3602328.html.

Pigg, Susan. "\$700-Million Arts-Focused Complex Planned for Queens Quay Site." thestar.com, March 26, 2015. Accessed August 6, 2016. https://www.thestar.com/ business/2015/03/26/700-million-arts-focused-complex-planned-for-queens-quaysite.html.

Ramkhalawansingh, Ceta. "Letter to the Toronto Preservation Board.” July 16, 2014. Shum, David. "Daniels Corporation Unveils Waterfront Mixed-Use Condo Project." Global News, March 26, 2015. Accessed August 2016. http://globalnews.ca/ news/1904704/daniels-corporation-to-unveil-waterfront-mixed-use-condo-project/.

Skinner, Justin. "OMB Settlement a Good Deal for Spadina and College Neighbourhood." InsideToronto.com, May 12, 2015. Accessed August 6, 2016. http://www.insidetoronto.com/news-story/5614271-omb-settlement-a-good-dealfor-spadina-and-college-neighbourhood/.

Strategies for a Creative City Project. "Toronto Case Study.” London-Toronto: 2006. "The Last Music Man." Interview of Dan Burke on Canadian Reflections (March 11, 2013), CBC Television. Accessed September 9, 2016. https://web.archive.org/ web/20131115092855/http://www.cbc.ca/player/Shows/ID/2341910245/.

"The Last Music Man.” Interview of Brendan Canning on Canadian Reflections (March 11, 2013), CBC Television. Accessed September 9, 2016. https://web.archive.org/ web/20131115092855/http://www.cbc.ca/player/Shows/ID/2341910245/.

Toronto and East York Community Council. “Agenda Item.” September 11, 2011. Accessed August 6, 2016. http://app.toronto.ca/tmmis/viewAgendaItemHistory. do?item=2011.TE9.93.

Toronto Cultural Planning, "Canada's Urban Waterfront: Waterfront Culture and Heritage Infrastructure Plan" (2001).

Toronto Preservation Board. “Agenda Item PB 3315, 'Heritage Evaluation - 484 Spadina Avenue - Waverley Hotel'.” July 17, 2014.

Toronto Preservation Board. "Recommendation re: Intention to Designate under Part IV, Section 29 of the Ontario Heritage Act - 484 Spadina Avenue.” March 31, 2014.

Toronto, Urban Design, City Planning Division. "Intention to Designate under Part IV, Section 29 of the Ontario Heritage Act - 484 Spadina Avenue.” March 20, 2014.

Toronto Waterfront Revitalization Corporation Act, SO 2002, c 28.

UNESCO Action Plan, "The Power of Culture - The Intergovernmental Conference on Cultural Policies for Development.” Stockholm: March-April 1998. Adopted April 2, 1998.

Valverde, Mariana. Everyday Law on the Street: City Governance in an Age of Diversity. Chicago: University of Chicago Press, 2012.

Valverde, Mariana. "Taking Land Use Seriously: Toward an Ontology of Municipal Law." Law, Text, Culture 9 (2005): 34-59.

Vaughan, Adam. Interview by Raju Mudhar, May 28, 2007. thestar.com. Accessed August 6, 2016. http://www.thestar.com/entertainment/2007/05/28/interview_ trascript_councillor_adam_vaughan.html. 


\section{Amps}

Vaughan, Adam. "Letter to the Toronto and East York Community Council." September 8, 2011.

"Waterfront Toronto." Accessed August 6, 2016. http://www.waterfrontoronto.ca.

Wheeler, Brad. "Why the Silver Dollar is Worth Saving." The Globe and Mail, January 23, 2015. Accessed August 6, 2016. http://www.theglobeandmail.com/ news/toronto/why-the-silver-dollar-is-worth-saving/article22606865/.

Wilson, Codi. "Silver Dollar Will Live on as Live Music Venue." CP24, May 8, 2015. Accessed August 6, 2016. http://www.cp24.com/news/silver-dollar-will-liveon-as-live-music-venue-1.2365609.

Winsa, Patty. "Toronto Rejects Proposal to Tear Down Hotel Waverly and Silver Dollar Room for Student Housing." thestar.com, January 15, 2014. Accessed August 6, 2016. http://www.thestar.com.

Winthrop, Robert. "Defining a Right to Culture, and Some Alternatives." Cultural Dynamics 14 (2002): 161-83.

Zukin, Sharon. Naked City: The Death and Life of Authentic Urban Places. Oxford: Oxford University Press, 2010. 